\title{
PENGARUH KOMPETENSI DAN MOTIVASI TERHADAP KINERJA KARYAWAN PT. BNI 46 (PERSERO) TBK UNIT KARTU KREDIT PALEMBANG
}

\author{
Pantani Dahlan \\ Dosen Tetap Fakultas Ekonomi Universitas Palembang
}

\begin{abstract}
ABSTRAK
Penelitian ini menguji pengaruh kompetensi dan motivasi terhadap kinerja karyawan PT. BNI 46 (persero) tbk unit kartu kredit Palembang. Tujuan penelitian ini adalah untuk mengetahui pengaruh kompetensi dan motivasi terhadap kinerja karyawan PT. BNI 46 (persero) tbk unit kartu kredit Palembang. Jenis penelitian ini mengunakan jenis penelitian asosiatif. Metode pengambilan sampelnya adalah probability sampling dengan teknik simple random sampling. Jenis data yang digunakan dalam penelitian ini adalah data primer dan data sekunder. Metode pengumpulan data penelitian ini menggunakan kuisioner dan dokumentasi. Analisis data yang digunakan adalah analisis kualitatif dan kuantitatif dengan teknik analisis regresi linier berganda. Hasil penelitian menunjukkan bahwa dari perhitungan $\mathrm{F}_{\text {hitung }}>\mathrm{F}_{\text {tabel }}$ dan $\mathrm{t}_{\text {tabel }}$. Berarti $\mathrm{H}_{\mathrm{o}}$ ditolak $\mathrm{H}_{\mathrm{a}}$ diterima yang artinya terdapat pengaruh Kompetensi $\left(\mathrm{X}_{1}\right)$ dan Motivasi $\left(\mathrm{X}_{2}\right)$ terhadap Kinerja Karyawan (Y), baik secara bersama-sama maupun parsial.
\end{abstract}

\section{Kata kunci : Kompetensi, Motivasi dan Kinerja Karyawan}

\section{I .PENDAHULUAN}

\subsection{Latar Belakang}

Sumber daya manusia sebagai salah

satu unsur yang sangat menentukan keberhasilan suatu perusahan dan memerlukan perhatian tersendiri karena akan mempengaruhi prestasi, loyalitas, serta kecintaan terhadap pekerjaan. Keadaan ini menciptakan sumber daya manusia sebagai asset yang sangat penting dan harus ditingkatkan efesiensinya untuk menghasilkan kinerja karyawan yang lebih baik.

Untuk mencapai tujuan organisasi, tentunya karyawan dituntut untuk memaksimalkan kinerja yang dia miliki. Kinerja karyawan adalah hal yang penting diperhatikan untuk organisasi, karena dapat mempengaruhi tercapainya tujuan dan kemajuan organisasi dalam suatu persaingan global yang berubah.

Terdapat faktor-faktor negatif yang dapat menurunkan kinerja karyawan, diantaranya adalah menurunnya keinginan karyawan untuk mencapai prestasi kerja, kurangnya motivasi, kurangnya ketetapan waktu dalam menyelesaikan pekerjaannya, pengaruh yang berasal dari lingkungannya, teman sekerja yang juga menurunkan semangat kerja.

Kinerja yang baik adalah kinerja yang optimal, yaitu kinerja yang sesuai standar organisasi dan mendukung tercapainya tujuann organisasi. Selain itu, kinerja perusahaan adalah tingkat pencapaian hasil dalam rangka mewujudkan perusahaan. Kinerja perusahaan dipengaruhi oleh banyak faktor yang dapat digolongkan pada faktor tujuan, standar, umpan balik, dan kompentasi. Hal ini dapat dilihat dari kinerja karyawan dalam suatu organisasi. Kinerja yang baik adalah kinerja yang optimal, yaitu kinerja yang sesuai standar organisasi dan mendukung tercapainya tujuan organisasi.

Kinerja perusahaan dipengaruhi oleh banyaknya faktor yang dapat digolongkan pada faktor tujuan, standar, umpan balik, kompetensi. Salah satu tujuan kinerja perusahaan PT. Bank BNI Persero 
Tbk Unit Kartu Kredit Palembang adalah yaitu perusahaan berharap kinerja yang dihasilkan oleh karyawan akan meningkat dan dapat membantu perusahaan mencapai tujuan yang telah ditetapkan, serta target penagihan kartu kredit (aset bank BNI) setiap bulan yang akan diakumulasikan tiap tahunnya terpenuhi. Tetapi pimpinan menyadari munculnya faktor-faktor penyebab yang berdampak kepada karyawannya sehingga cenderung asal saja dalam bekerja, menurunnya kinerja karyawan disebabkan kurangnya kompetensi dan disiplin kerja yang diterapkan pimpinan masih belum cukup bagi karyawan, serta masih banyaknnya faktor yang seharusnya memfasilatasi dan menjadikan sebagai nilai tambah justru menjadi penyebab penurunan kinerja karyawan.

Kuantitas hasil kerja pada karyawan PT. Bank BNI Persero Tbk Unit Kartu Kredit Palembang ini sebagian maksimal, berdasarkan wawancara hal itu dijelaskan karena di dalam setiap proses produksi pihak perusahaan telah mengeluarkan biaya cukup besar akan sangat merugikan perusahaan apabila hasil yang didapatkan tidak memenuhi target dari perusahaan. Terkadang waktu yang ditargetkan perusahaan untuk menyelesaikan target penagihan kartu kredit (aset nank BNI) tidak tercapai, karena melebihi waktu yang telah ditentukan. Masalah ketepatan waktu seperti karyawan datang terlambat, stres saat bekerja, melebihi waktu jam istirahat,dan melebihi waktu produksi. Karyawan yang sering membuat ulah atau perilakunya negatif di tempat kerja. Dengan begitu, dikhawatirkan tugas pokok dan fungsi dari karyawan yang bersangkutan terganggu. Selain itu, kinerja secara umum di dalam perusahaan juga tidak menutup kemungkinan ikut terganggu. Dapat dilihat dari kualitas kerja karyawan PT. Bank BNI Persero Tbk Unit Kartu kredit Palembang yaitu sering kedapatan menggunakan gadget pada jam kerja, sering menunda pekerjaan yang telah diberikan, beban kerja yang terlalu padat.
Kesesuaian antara Kompetensi dan Motivasi yang diterapkan dengan apa yang diharapkan bawahan menjadi suatu masalah yang harus diperhatikan karena dapat mempengaruhi kinerja karyawan untuk mencapai tujuan perusahaan. Seperti pada karyawan PT. Bank BNI Persero Tbk Unit Kartu Kredit Palembang sebagai perusahaan milik negara di indonesia memahami bahwa faktor Motivasi berperan penting dalam perkembangan PT. Bank BNI Persero Tbk Unit Kartu Palembang. Pemimpin perusahaan harus menyadari bahwa perubahan akan terus ada sejalan dengan perkembangan perusahaan. Semakin besar ukuran perusahaan akan cenderung menjadi kompleks keadaannya yang merupakan sumber potensial untuk timbulnya konflik. Dalam menangani kondisi tersebut, PT. Bank BNI Persero Tbk Unit Kartu Kredit Palembang serta memerlukan cara mengatasi konflik yang ada tanpa mengurangi kinerja dari karyawannya sehingga dapat memotivasi karyawan tersebut.

Motivasi yang diberikan pimpinan perusahaan belum sepenuhnya sesuai dengan yang diharapkan oleh karyawan penagihan kartu kredit, kondisi ini dapat ditandai dengan tempat kerja pada PT. Bank BNI Persero Tbk Unit Kartu Palembang, tempat bekerja karyawan sempit dikarenakan banyaknya jumlah karyawan meskipun pendingin ruangan telah dinyalakan tapi masih menimbulkan ketidaknyamanan dan gerah, sehingga sebagaian karyawan tidak fokus dan akibatnya lalai dalam menjalankan pekerjaannya, adanya motivasi dan mementingkan setiap bulan menerima gaji/upah saja, tanpa memikirkan hasil yang optimal dan tanggung jawab yang menjadi kewajibannya oleh sebagaian karyawan menyebabkan karyawan tetap khususnya merasa lalai dan kalah bersaing dengan karyawan kontrak. Adapun pelatihan kerja pada PT. Bank BNI Persero Tbk Unit Kartu Kredit Palembang yang telah diberikan kepada karyawan tetap maupun kontrak tidak selalu sama. Walaupun keduanya 
mendapatkan pelatihan kerja, karyawan tetap mendapatkan pelatihan lebih profesional di bandingkan karyawan kontrak sedangkan karyawan kontrak mendapatkan pelatihan standar. Semua fasilitas yang disediakan oleh perusahaan dalam berkerja hal ini bahkan membuat tidak sedikit karyawan tetap merasa aman, nyaman dan merasa berada dalam lingkungan kerja rendah resiko serta tanpa kekhawatiran yang berdampak kinerja karyawan stagnan. Hal ini dapat terlihat dari banyaknya karwayan kontrak yang mampu melakukan perkerjaan lebih baik dari karyawan dan mencapai target penagihan kartu kredit juga memenuhi semua kewajibannya dalam berkerja, sebaliknya jika dibandingkan dengan karyawan tetap yang sebagian tidak dapat mencapainnya.

Hasil penelitian teradahulu tentang pengaruh kinerja dan motivasi karyawan masih memperlihatkan hasil yang tidak konsisten. Berdasarkan penelitian uraian di atas maka penulis tertarik untuk menggunakan judul "PENGARUH KOMPETENSI DAN MOTIVASI TERHADAP KINERJA KARYAWAN PT. BNI 46 (PERSERO) TBK UNIT KARTU KREDIT PALEMBANG".

\subsection{Perumusan Masalah}

Berdasarkan uraian di atas maka yang menjadi permasalahan dalam penelitian ini adalah sebagai berikut:

1. Adakah pengaruh kompetensi dan motivasi terhadap kinerja karyawan PT. BNI 46 (persero) tbk unit kartu kredit Palembang?

2. Adakah pengaruh kompetensi terhadap kinerja karyawan pada PT. BNI 46 (persero) tbk unit kartu kredit Palembang?

3. Adakah pengaruh motivasi terhadap kinerja karyawan PT. BNI 46 (persero) tbk unit kartu kredit Palembang?

\subsection{Tujuan Penelitian}


keterampilan dan pengetahuan serta didukung oleh sikap kerja yang dituntut oleh pekerjaan tersebut. Dengan demikian, kompetensi menunjukan keterampilan atau pengetahuan yang dicirikan oleh profesionalisme dalam suatu bidang tertentu sebagai sesuatu yang terpenting sebagai unggulan bidang tersebut.

Menurut Spencer dan Spencer dalam (Wibowo 2017:272) menyatakan bahwa kompetensi merupakan landasan dasar karakteristik orang dan mengindikasikan cara berperilaku atau berpikir, menyamakan situasi, dan mendukung untuk periode waktu cukup lama.

Terdapat lima tipe karakteristik kompetensi, yaitu sebagai berikut:

1. Motif adalah sesuatu yang secara konsisten dipikirkan atau diinginkan orang yang menyebabkan tindakan. Motif mendorong, mengarahkan, dan memilih perilaku menuju tindakan atau tujuan tertentu.

2. Sifat adalah karakteristik fisik dan respons yang konsisten terhadap situasi atau informasi. Kecepatan reaksi dan ketajaman mata merupakan ciri fisik kompetensi seorang pilot tempur.

3. Konsep diri adalah sikap, nilai-nilai, atau citra diri seseorang. Percaya diri merupakan keyakinan orang bahwa mereka dapat efektif dalam hampir setiap situasi adalah bagian dari konsep orang.

4. Pengetahuan adalah informasi yang dimiliki orang dalam bidang spesifik. Pengetahuan adalah kompetensi yang kompleks. Skor pada tes pengetahuan sering gagal memprediksi prestasi kerja karena gagal mengukur pengetahuan dan keterampilan dengan cara yang sebenarnya dipergunakan dalam pekerjaan.

5. Keterampilan adalah kemampuan mengerjakan tugas fisik atau mental tertentu. Kompetensi mental atau keterampilan kognitif termasuk berpikir analitis dan konseptual.।
Menurut Zwell dalam (Wibowo 2017:283) beberapa faktor yang mempengaruhi kompetensi sebagai berikut:

1. Keyakinan dan Nilai-Nilai

Yaitu Keyakinan orang tentang dirinya maupun terhadap orang lain akan sangat mempengaruhi perilaku. Apabila orang percaya bahwa mereka tidak kreatif dan inovatif, mereka tidak akan berusaha berpikir tentang cara baru atau berbeda dalam melakukan sesuatu.

2. Pengalaman

Yaitu kehalian dari banayak kompetensi memerlukan pengalaman mengorganisasi orang, komunikasi di hadapan kelompok, menyelesaikan masalah, dan sebagainya. Orang yang tidak pernah berhubungan dengan organisasi besar dan kompeks tidak mungkin mengembangkan kecerdasan organisasional untuk memahami dinamika kekuasaan dan pengaruh dalam lingkungan tersebut.

3. Keterampilan

Keterampilan memainkan peran di kebanyakan kompetensi berbicara di depan umum merupakan keterampilan yang dapat dipelajari, dipraktikan, dan diperbaiki. Keterampilan menulis juga dapat diperbaiki dengan instruksi, praktik, dan umpan balik.

4. Karakteristik Kepribadian

Yaitu kepribadian dapat mempengaruhi keahlian manajer dan pekerja dalam sejumlah kompetensi, termasuk dalam penyelesaian konflik, menunjukan kepedulian interpersonal, kemampuan bekerja dalam tim, memberikan pengaruh dan membangun hubungan.

5. Motivasi

Merupakan faktor dalam kompetensi yang dapat berubah. Dengan memberikan dorongan, apresiasi terhadap pekerjaan bawahan, memberikan pengakuan dan perhatian individual dari atasan dapat mempunyai 
oengaruh positif terhadap mtivasi seseorang bawahan.

6. Isu Emosional

Hambatan emosional dapat membatasi penguasaan kompetensi. Takut membuat kesalahan, menjadi malu, merasa tidak disukai atau tidak menjadi bagian, semuanya cenderrung membatasi motivasi dan inisiatif.

7. Kemampuan Intelektual

Kompetensi tergantung pada pemikiran kognitif seperti pemikiran konseptual dan pemikiran analitis.

8. Budaya Organisasi

Budaya organisasi mempengaruhi kompetensi sumber daya manusia dalam kegiatan sebagai berikut:

1) Praktik rekrutmen dan seleksi karyawan mempertimbangkan siapa diantara pekerja yang dimasukan dalam organisasi dan tingkat keahliannya tentang kompetensi.

2) Sistem penghargaan mengomunikasikan pada pekerja bagaimana organisasi menghargai kompetensi.

3) Praktik pengambilan keputusan memengaruhi kompetensi dalam memberdayakan orang lain, inisiatif, dan memotivasi orang lain.

4) Filosofi organisasi-misi,visi dan nilai-nilai berhubungan dengan semua kompetensi.

5) Kebiasaan dan prosedur memberi informasi kepada pekerja tentang berapa banyak kompetensi yang diharapkan.

6) Komitmen pada pelatihan dan pengembangan mengomunikasikan pada pekerja tentang pentingnya kompetensi tentang pembangunan berkelanjutan.

7) Proses organisasional yang mengembangkan pemimpin secara langsung memengaruhi kompetensi kepemimpinan

\subsubsection{Motivasi}

Menurut Malayu S.P.Hasibuan (2016: 218) motif adalah suatu perangsang keinginan (want) dan daya penggerak kemauan bekerja seseorang. Setiap motif mempunyai tujuan tertentu yang ingin dicapai.

Menurut Viethzal Rivai (2011:838) beberapa faktor yang mempengaruhi motivasi sebagai berikut:

1. Lingkungan Kerja

Yaitu segala sesuatu atau kondisi yang dirasakan disekitar para karyawan yang biasanya berpengaruh pada diri karyawan didalam pelaksanaan tugasnya, seperti hubungan antara atasan dan bawahan yang harmonis.

2. Gaji yang adil dan Kompetitif

Yaitu balas jasa yang diterima karyawan sebagai konsekuensinya dan status sebagai karyawan yang memberi kontribusi dalam tujuan perusahaan.

3. Insentif

Yaitu pendorong atau perangsang diluar gaji yang diberikan dengan sengaja kepada karyawan agar timbul semangat yang besar untuk berprestasi.

4. Bonus

Masing-masing karyawan memperoleh imbalan yang sesuai dengan tugas, jabatan dan prestasi kerjanya dalam bentuk bonus.

5. Rasa aman dalam bekerja

Dalam hal ini rasa aman dalam bekerja merupakan hal yang dapat membuat karyawan merasa terpelihara oleh perusahaan, seperti perusahaan yang memberikan jaminan asuransi kesehatan kepada karyawan sehingga sewaktuwaktu dalam keadaan sakit tidak perlu mengeluarkan biaya terlalu banyak.

1) Penghargaan atau prestasi kerja Yaitu karyawan akan merasa senang apabila hasil kerja yang dicapai lebih baik serta akan menjadi bangga apabila atasan memberikan penghargaan kepada mereka yang berprestasi. 
2) Prilaku adil dari manajemen

Karyawan atau pegawai yang memiliki prestasi kerja dan akan tetap diperhatikan, fasilitas, penerapan disiplin kerja baik bagi semua karyawan juga pimpinan tanpa pilih kasih. Bila hanya karyawan atau pegawai mendapatkan perlakuan yang adil dari manajemen, maka mereka akan lebih giat dalam bekerja dan menimbulkan sikap profesional dalam bekerja untuk perusahaan demi mewujudkan tujuan perusahaan.

\subsubsection{Kinerja}

Pengertian performance sebagai hasil kerja atau prestasi kerja. Namun, sebenarnya kinerja mempunyai makna yang lebih luas, bukan hanya hasil kerja, tetapi Menurut Kasmir (2019:182) kinerja merupakan hasil kerja dan perilaku kerja seseorang dalam suatu periode, biasanya 1 tahun. Kemudian kinerja dapat diukur dari kemampuannya menyelesaikan tugas-tugas dan tanggung jawab yang diberikan.

Menurut Kasmir (2016:189-193), faktor-faktor yang mempengaruhi kinerja adalah sebagai berikut:

1. Kemampuan dan Keahlian

Merupakan kemampuan atau skill yang dimiliki seseorang dalam melakukan suatu pekerjaan. Semakin meemiliki kemampuan dan keahlian maka akan dapat menyelesaikan pekerjaannya secara benar, sesuai dengan yang telah ditetapkan.

2. Pengetahuan

Maksudnya adalah pengetahuan tentang pekerjaan. Seseorang yang memiliki pengetahuan tentang pekerjaan secara baik akan memberikan hasil pekerjaan yang baik, demikian pula sebaliknya.

3. Rancangan Kerja

Merupakan rancangan pekerjaan yang akan memudahkan karyawan dalam mencapai tujuannya.

4. Kepribadian

Yaitu kepribadian seseorang atau karakter yang dimiliki seseorang. Setiap orang memiliki kepribadian atau karakter yang berbeda satu sama lainnya. Seseorang yang memiliki kepribadian atau karakter yang baik, akan dapat melakukan pekerjaan secara sungguh-sungguh penuh tanggung jawab sehingga hasil pekerjaannya juga baik. Demikian pula sebaliknya bagi karyawan yang memiliki kepribadian atau karakter yang buruk, akan bekerja secara tidak sungguh-sungguh dan kurang bertanggung jawab dan pada akhirnya hasil pekerjaannya pun tidak atau kurang baik dan tentu saja hal ini akan mempengaruhi kinerja yang ikut buruk pula.

5. Motivasi Kerja

Motivasi kerja merupakan dorongan bagi seseorang untuk melakukan pekerjaan. Jika karyawan memiliki doronga yang kuat dari dalam dirinya atau dorongan dari luar dirinya (misalnya dari pihak perusahaan), maka karyawan akan terangsang atau terdorong untuk melakukan sesuatu dengan baik.

6. Kepemimpinan

Kepemimpinan merupakan perilaku seorang pemimpin dalam mengatur, mengola dan memerintah bawahannya untuk mengerjakan sesuatu tugas dan tanggung jawab yang diberikannya.

7. Gaya Kepemimpinan

Merupakan gaya atau sikap seorang pemimpin dalam mengadapi atau memerintahkan bawahannya.

8. Budaya Organisasi

Merupakan kebiasaan-kebiasaan atau norma-norma yang berlaku dan dimiliki oleh suatu organisasi atau perusahaan.

9. Kepuasaan Kerja

Merupakan perasaan senang atau gembira, atau perasaan suka seseorang sebelum dan setelah melakukan suatu pekerjaan.

10. Lingkungan Kerja 
Merupakan suasana atau kondisi di sekitar lokasi tempat bekerja. Lingkungan kerja dapat berupa ruangan, layout, sarana dan prasarana, serta hubungan kerja dengan sesama rekan kerja.

11. Loyalitas

Merupakan kesetiaan karyawan untuk tetap bekerja dan membela perusahaan di mana tempatnya bekerja. Kesetian ini ditunjukkan dengan terus bekerja sungguh-sungguh sekalipun perusahaannya dalam kondisi yang kurang baik.

12. Komitmen

Merupakan kepatuhan karyawan untuk menjalanka kebijakan atau peraturan perusahaan dalam bekerja. Komitmen juga diartikan kepatuhan karyawan kepada janji-janjii yang telah dibuatnya.

13. Disiplin Kerja

Merupakan usaha karyawan untuk menjalankan aktivitas kerjanya secara sungguh-sungguh. Disiplin kerja dalam hal ini dapat berupa waktu, misalnya masuk kerja selalu tepat waktu.

\section{Adapun enam kategori yang} digunakan untuk mengukur kinerja secara individual sebagai berikut:

1. Kualitas

Kualitas adalah tingkat dimana hasil aktivitas yang dilakukan mendekati sempurna dalam arti menyesuaikan beberapa cara ideal dari penampilan aktivitas ataupun memenuhi tujuan yang diharapkan dari suatu aktivitas.

2. Kuantitas

Kuantitas adalah jumlah yang dihasilkan dinyatakan dalam istilah sejumlah unit dan jumlah siklus aktivitas yang diselesaikan.

3. Ketepatan Waktu

Ketepatan waktu adalah tingkat suatu aktivitas yang diselesaikan pada waktu awal yang diinginkan, dilihat dari sudut koordinasi dengan hasill outout serta memaksimalkan waktu yang tersedia untuk aktivitas lain.

4. Efektifitas

Efektifitas adalah tingkat penggunaan sumber daya organisasi dimaksimalkan dengan maksud menaikkan keuntungan atau mengurangi kerugian dari setiap unit data penggunaan sumber daya.

5. Kemandirian

Kemandirian adalah tingkat dimana karyawan dapat melakukan fungsi kerjanya tanpa bantuan, bimbingan dari pengawas atau meminta turut campurnya pengawas guna menghindari hasil yang merugikan.

6. Komitmen Kerja

Komitmen kerja adalah tingkat dimana karyawan mempunyai komitmen kerja karyawan dan tanggung jawab karyawan terhadap peruasahaan

\subsection{Penelitian Terdahulu}

Terdapat lima jurnal yang relevan dengan penelitian ini. Kelimanya merupakan jurnal nasional. Penelitian pertama oleh Apri Biman Santoso (2019) yang berjudul "Pengaruh Kompetensi dan Motivasi Terhadap Kinerja Karyawan Pada PT.Sumber Berkah Indonesia (SBI) (Prabumulih)".

Tujuan penelitian ini adalah untuk mengetahui pengaruh kompetensi dan motivasi terhadap kinerja karyawan pada PT.Sumber Berkah Indonesia. Data yang digunakan dalam penelitian ini adalah data primer. Metode pengumpulan data yang digunakan adalah kuisioner. Analisis yang digunakan adalah kualitatif. Alat analisis yang digunakan yaitu regresi linier berganda. Dengan menggunakan uji $\mathrm{F}$ dan uji T. Hasil regresi linier berganda menunjukan, variabel kompetensi berpengaruh secara signifikan terhadap kinerja karyawan dengan nilai $\mathrm{t}$ hitung 5,633 $>\mathrm{t}$ tabel 1,982. Variabel motivasi menunjukan nilai $\mathrm{t}$ hitung 2,159>t tabel 1,982 hal ini berarti berpengaruh secara signifikan terhadap kinerja karyawan. Hasil $\mathrm{F}$ hitung sebesar 19,374 $>\mathrm{F}$ tabel 3,081. 
Bahwa terdapat pengaruh yang signifikan antara variabel kompetensi dan motivasi secara simultan berpengaruh terhadap kinerja karyawan.

Penelitian kedua oleh Ron Rozada (2020) dengan judul Pengaruh Kompetensi, Motivasi Kerja dan Disiplin Kerja Terhadap Kinerja Dosen Pada Fakultas Ekonomi dan Bisnis di Universitas Muhammadiyah Gresik. Penelitian ini bertujuan untuk mengetahui Pengaruh Kompetensi, Motivasi Kerja dan Disiplin Kerja terhadap Kinerja dosen pada Fakultas Ekonomi dan Bisnis di Universitas Muhammadiyah Gresik. Sampel dalam penelitian ini menggunakan sampling jenuh yaitu semua anggota populasi digunakan sebagai sampel besarnya sampel yang digunakan sebanyak 34 responden. Teknik pengumpulan data melalui penyebaran kuisioner. Teknik analisis yang digunakan adalah regresi linier berganda. Hasil dari penelitian ini menunjukan bahwa variabel Kompetensi berpengaruh terhadap Kinerja Dosen, variabel Motivasi Kerja tidak berpengaruh terhadap Kinerja Dosen. Disiplin Kerja berpengaruh terhadap Kinerja Dosen pada Fakultas Ekonomi dan Bisnis di Universitas Muhammadiyah Gresik.

\subsection{Kerangka Berfikir}

Berdasarkan dari uraian tinjauan pustaka pada bagian sebelumnya, maka kerangka fikir pada penelitian ini dapat di lihat dari gambar 2.1

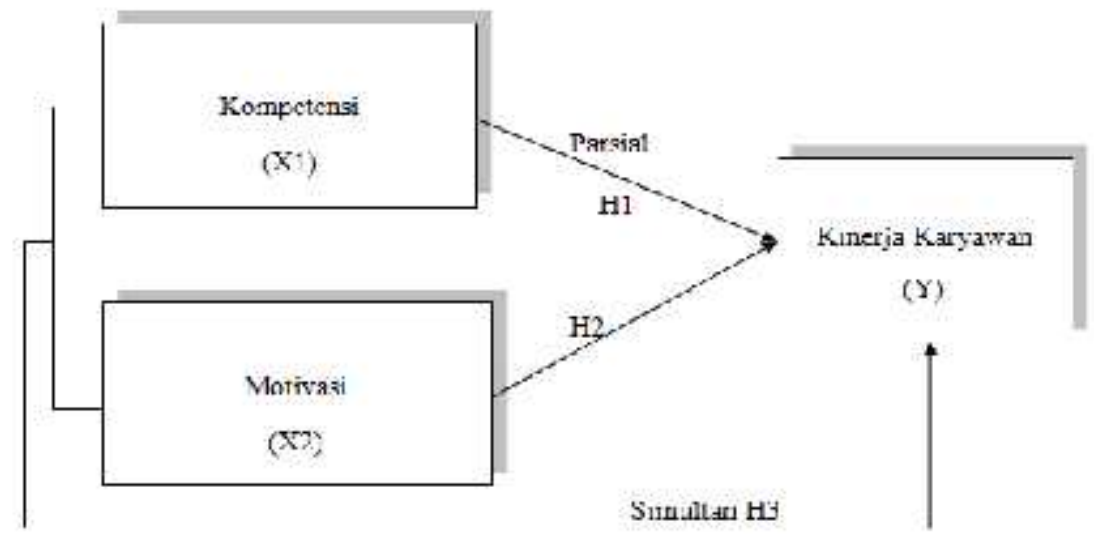

\subsection{Hipotesis}

Dari kerangka pemikiran Pengaruh Kompetensi dan Motivasi terhadap kinerja karyawan PT. Bank BNI 46 (Persero) Tbk unit kartu kredit Palembang sebagai berikut:

1. Ada pengaruh kompetensi dan motivasi terhadap kinerja karyawan PT. Bank BNI 46 (Persero) Tbk unit kartu kredit Palembang?.

2. Ada pengaruh kompetensi terhadap kinerja karyawan PT. Bank BNI 46 (Persero) Tbk unit kartu kredit Palembang?.

3. Ada pengaruh motivasi terhadap kinerja karyawan PT. Bank BNI 46 (Persero) Tbk unit kartu kredit Palembang?.
III. METODOLOGI PENELITIAN

3.1 Objek Penelitian

Objek penelitian merupakan permasalahan yang di teliti, menurut Sugiyono (2017), objek penelitian adalah suatu atribut dari orang, objek atau kegiatan yang mempunyai variasi tertentuyang ditetapkan oleh peneliti untuk dipelajari kemudian ditarik kesimpulannya. objek penelitian ini adalah kompetensi, motivasi serta pengaruhnya terhadap kinerja karyawan

Subjek penelitian merupakan tempat variabel melekat. subjek penelitian adalah tempat dimana data untuk variabel penelitian diperoleh (Arikunto, 2010). Subjek penelian ini adalah PT Bank BNI 46 (Persero) Tbk Unit Kartu Kredit 
Palembang.Penelitian ini dilakukan di gedung BNI cabang Jembatan Ampera Lantai 3 Unit Kartu Kredit Palembang yang beralamat jalan masjid lama nomor 61 kota Palembang, alamat surat elektronik Septi.wulandari@bni.co.id nomor telepon 0711-362619

\subsection{Ruang Lingkup Penelitian}

Ruang lingkup penelitian digunakan untuk memberikan gambaran yang jelas terhadap pembahasan, serta agar analisis menjadi tearah dan sesuai dengan masalah yang ada, maka peneliti membatasi pebahasan pada perusahaan PT. Bank BNI 46 (Persero) Tbk Unit Kartu Kredit Palembang, di mana indikator kinerja karyawan adalah tujuan, standar, umpan balik, dan indikator kompetensi adalah pengetahuan, keterampilan, perilaku sedangkan indikator motivasi menggunakan gaji, tanggungjawab, Penghargaan.

\subsection{Desain Penelitian}

Menurut Sugiyono (2017), jenis penelitian jika dilihat dari tingkat eksplanasinya terdiri dari tiga macam, yaitu :

1. Penelitian Deskriptif

Yaitu salah satu jenis penelitian yang tujuannya untuk mengetahui variabel mandiri baik satu variabel atau lebih tanpa membuat perbandingan atau menghubungkan dengan variabel lainnya.

2. Penelitian Komparatif

Yaitu penelitian yang bersifat membandingkan atau berupa hubungan sebab akibat antara dua variabel atau lebih dari satu variabel.

3. Penelitian Assosiatif

Yaitu penelitian yang bertujuan untuk mengetahui antara dua variabel atau lebih.

Penelitian ini adalah jenis penelitian assosiatif, yaitu mengetahui pengaruh dan hubungan kompetensi dan motivasi terhadap kinerja karyawan.

\subsection{Jenis dan Sumber Data}

Syofian Siregar (2010:128) data dapat dilihat dari sumber datanya terdiri atas dua jenis, antara lain:

1. Data Primer

Adalah data yang dikumpulkan sendiri ole peneliti langsung dari sumber pertama atau tempat objek penelitian dilakukan. Data ini diperoleh melalui observasi dilingkungan PT Bank BNI 46 (Persero) Tbk Unit Kartu Kredit Palembang, membagikan kuesioner kepada responden di PT Bank BNI 46 (Persero) Tbk Unit Kartu Kredit Palembang dan wawancara langsung dengan pimpinan dan staff perusahaan sesuai dengan kebutuhan dalam penelitian ini.

2. Data Sekunder

Adalah data yang diterbitkan atau digunakan oleh organisasi yang bukan pengelolahannya. Data ini diperoleh dari dokumen perusahaan sebagai tempat objek penelitian yaitu PT Bank BNI 46 (Persero) Tbk Unit Kartu Kredit Palembang dan buku-buku literatur yang memberikan referensi dan informasi mengenai kompetensi, motivasi, dan kinerja.

Data yang diperlukan dalam penelitian ini adalah data primer dan data sekunder sebab dengan menggunakan data primer kita bisa langsung memberikan kuesioner yang diisi oleh responden, sedangkan data sekunder kita tidak langsung memberikan data kepada pengumpul data.

$$
\text { Menurut Sugiyono (2013:194) }
$$

dilihat dari segi cara atau teknik ppengumpulan data dapat dilakukan dengan berbagai cara, antara lain sebagai berikut:

1. Interview 
Digunakan sebagai teknik pengumpulan data, apabila peneliti ingin melakukan studi pendahuluan untuk menemukan permasalahan yang harus diteliti, dan apabila peneliti ingin mengetahui halhal dari responden yang lebih mendalam dan jumlah responnya sedikit/kecil.

2. Angket/Kuesioner

Adalah sebagai teknik pengumpulan data yang dilakuan dengan cara memberi seperangkat pertanyaan tertulis kepada responden untuk dijawabnya.

3. Observasi

Adalah sebagai teknik pengumpulan data mempunyai ciri yang spesifik bila dibandingkan dengan teknik yang lain, yaitu wawancara dan kuesioner. Jika wawancara dan kuesioner selalu berkomunikasi dengan orang, maka observasi tidak terbatas pada orang, tetapi juga objek alam yang lain. Jadi bisa disimpulkan observasi bisa digunakan tidak hanya untuk berkomunikasi dengan orang tetapi dengan siapa pun objek lain.

Teknik pengumpulan data yang digunakan dalam penelitian ini adalah kuesioner dan dokumentasi. Kuesioner dilakukan dengan memberikan daftar pernyataan sesuai dengan yang akan diteliti. Sedangkan dokumentasi yaitu dengan menerima data dari PT. Bank BNI 46 (Persero) Tbk Unit Kartu Kredit Palembang.

\subsection{Populasi dan Sampel}

\subsubsection{Populasi}

Menurut Sugiyono (2013:115) mendefinisikan bahwa populasi adalah wilayah generalisasi yang terdiri atas objek/subjek yang mempunyai kualitas dan karakteristik tertentu yang di tetapkan oleh peneliti untuk di pelajari dan kemudian ditarik kesimpulannya. Populasi dalam penelitian ini adalah karyawan PT. Bank BNI 46 (Persero) Tbk Unit Kartu Kredit Palembang berjumlah 76 orang yang diklasifikasikan sebagai berikut.

Tabel 3.1

Jumlah Karyawan PT Bank BNI 46 (Persero) Tbk Unit Kartu Kredit Palembang

\begin{tabular}{|c|l|c|}
\hline No & \multicolumn{1}{|c|}{ Departemen } & Jumlah (orang) \\
\hline 1 & Manajer & 1 \\
2 & SPV/Maintenance & 2 \\
3 & Team Leader & 6 \\
4 & Penagihan & 63 \\
5 & Personalia/ Admin & 3 \\
6 & Office Boy & 1 \\
& Jumlah & 76 \\
\hline
\end{tabular}

Sumber: Pengambilan berdasarkan jumlah karyawan PT Bank BNI 46 (persero) tbk unit kartu kredit palembang

\subsubsection{Sampel}

Sampel adalah bagian dari jumlah dan karakteristik yang dimiliki oleh populasi tersebut (Sugiyono,2015:81). Sampel yang digunakan dalam penelitian ini berdasarkan tabel penentuan jumlah dari populasi tertentu dengan tingkat kesalahan 5\% (Sugiyono,2015:87) dari jumlah populasi 76 orang maka jumlah sampel diketahui adalah 72 karyawan PT. Bank BNI 46 (Persero)

Tbk Unit Kartu Kredit Palembang. 
Tabel 3.2

Kerangka Sampel

\begin{tabular}{|c|l|c|}
\hline No & \multicolumn{1}{|c|}{ Unit Kartu Kredit Palembang } & Sampel \\
\hline 1 & Manajer & $(1: 76) \times 72=1$ \\
2 & SPV/ Maintenance & $(2: 76) \times 72=2$ \\
3 & Team Leader & $(6: 76) \times 72=6$ \\
4 & Penagihan & $(63: 76) \times 72=59$ \\
5 & Personalia/ Admin & $(3: 76) \times 72=3$ \\
6 & Office Boy & $(1: 76) \times 72=1$ \\
& Jumlah & 72 \\
\hline
\end{tabular}

Sumber: rumus pengambilan sampel menurut sugiyono (2015) (Jumlah karyawan 76

$\mathrm{x}$ Tingkat kesalahan $5 \%=3.8,76-3.8=72.2$ )

Metode pengambilan sampel dalam penelitian ini adalah probability sampling dengan teknik simple random sampling sampling yaitu digunakan bila populasi mempunyai anggota/unsur yang tidak homogen dan berstrata secara proporsional.

\subsection{Definisi Operasional dan Pengukuran Variabel \\ 1. Definisi Opoerasional}

Tabel 3.3

Operasionalisasi Variabel

\begin{tabular}{|c|c|c|}
\hline Variabel & Definisi Variabel & Indikator \\
\hline $\begin{array}{l}\text { Kinerja } \\
\text { Karyawan } \\
\quad(Y)\end{array}$ & $\begin{array}{l}\text { Kinerja adalah suatu keadaan secara utuh atas perusahaan } \\
\text { selama periode waktu tertentu pada PT. Bank BNI } 46 \\
\text { (Persero) Tbk Unit Kartu Kredit Palembang }\end{array}$ & $\begin{array}{l}\text { 1.Tujuan } \\
\text { 2.Standar } \\
\text { 3.Umpan balik }\end{array}$ \\
\hline $\begin{array}{l}\text { Kompeten } \\
\text { si } \\
\text { (XI) }\end{array}$ & $\begin{array}{l}\text { Kompetensi adalah suatu kemampuan untuk } \\
\text { melaksanakan atau melakukan suatu pekerjaan atau tugas } \\
\text { yang dilandasi atas keterampilan dan pengetahuan serta } \\
\text { didukung oleh sikap kerja yang dituntut oleh pekerjaan } \\
\text { tersebut }\end{array}$ & $\begin{array}{l}\text { 1.Pengetahuan } \\
\text { 2.Keterampila } \\
\text { n } \\
\text { 3.Perilaku }\end{array}$ \\
\hline $\begin{array}{c}\text { Motivasi } \\
\text { (X2) }\end{array}$ & $\begin{array}{l}\text { Merupakan serangkaian proses yang membangkitkan } \\
\text { (arouse), mengarahkan (direct), dan menajaga (maintain) } \\
\text { perilaku manusia menuju pada pencapaian tujuan PT. } \\
\text { Bank BNI } 46 \text { (Persero) Tbk Unit Kartu Kredit } \\
\text { Palembang. }\end{array}$ & $\begin{array}{l}\text { 1.Gaji } \\
\text { 2.Tanggung } \\
\text { Jawab } \\
\text { 3.Penghargaan }\end{array}$ \\
\hline
\end{tabular}

Sumber: Veithzal Rivai (2014), Wibowo (2017),Malayu S.P Hasibuan (2007)

\section{Pengukuran Variabel}

Skala pengukur variabel yang digunakan dalam penelitian ini adalah skala likert. Sugiyono (2015: 165), menyatakan "Skala likert adalah skala yang bertujuan untuk membedakan indikator dalam suatu 
variabel dengan asumsi bahwa ada urutan atau tingkat skala, dimana responden menyatakan tingkat setuju mengenai berbagai pernyataan perilaku, objek, orang atau kejadian. Dalam melakukan penelitian terhadap variabel-variabel yang akan di uji, pada setiap jawaban akan diberi skor."

Skala likert menggunakan lima tingkatan jawaban yang dapat terbentuk sebagai berikut:

Tabel 3.4

Instrument Skala Likert

\begin{tabular}{|c|l|c|}
\hline No & \multicolumn{1}{|c|}{ Pernyataan } & Skor \\
\hline 1 & Sangat Tidak Setuju (STS) & 1 \\
\hline 2 & Tidak Setuju (TS) & 2 \\
\hline 3 & N (Netral) & 3 \\
\hline 4 & Setuju (S) & 4 \\
\hline 5 & Sangat Setuju (SS) & 5 \\
\hline
\end{tabular}

\subsection{Teknik Analisis}

Teknik analisis data adalah suatu metode atau cara untuk mengolah sebuah data menjadi informasi sehingga karakteristik data tersebut menjadi mudah untuk dipahami dan juga bermanfaaat untuk menemukan solusi permasalahan. Analisis regresi linier berganda adalah hubungan secara linier antara dua atau lebih variabel indipenden $\left(\mathrm{X}_{1}, \mathrm{X}_{2}\right)$ dengan variabel dependen $(\mathrm{Y})$. Analisis ini untuk mengatahui arah hubungan antara variabel independen dengan variabel dependen apakah masingmasing variabel independen berhubungan positif atau negatif dan untuk memprediksi nilai dari variabel dependen mengalami kenaikan atau penurunan. Data yang digunakan biasanya berskala interval atau rasio.

Persamaan regresi linier berganda sebagai berikut:

$$
\mathbf{Y}=\mathbf{a}+\mathbf{b}_{1} \mathbf{X}_{1}+\mathbf{b}_{2} \mathbf{X}_{2}+\mathbf{e}_{1}
$$

Dimana :

$\mathrm{Y}=$ Kinerja Karyawan

a $=$ Bilangan konstanta, bila $\mathrm{X}_{1}$ dan $\mathrm{X}_{2}$

$=0$ maka

$\mathrm{b}_{1,2}=$ Koefisienregresi regresi berganda

$\mathrm{X}_{1} \quad=$ Kompetensi

$\mathrm{X}_{2} \quad=$ Motivasi $\mathrm{e}_{1}=$ Standar Error

\subsubsection{Uji F (ANOVA)}

Pengujian hipotesis secara bersama merupakan pengujian hipotesis koefisien regresi berganda dengan $B_{1}$ dan $B_{2}$ secara bersama-sama mempengaruhi

a. Merumuskan Hipotesis

$\mathrm{H}_{\mathrm{o}}$ : Tidak ada pengaruh kompetensi dan motivasi terhadap kinerja karyawan PT. Bank BNI 46 (Persero) Tbk Unit Kartu Kredit Palembang.

$\mathrm{H}_{\mathrm{a}}$ : Ada pengaruh kompetensi dan motivasi terhadap kinerja karyawan PT. Bank BNI 46 (Persero) Tbk Unit Kartu Kredit Palembang.

b. Menentukan Taraf Nyata

Tingkat signifikan sebesar 5\%, Taraf nyata dari $t$ tabel ditentukan dari derajat bebas $(\mathrm{db})=\mathrm{n}-\mathrm{k}-1$, Taraf nyata (a) berarti nilai $\mathrm{F}$ tabel, Taraf nyata dari $\mathrm{F}$ tabel ditentukan dengan derajat bebas $(\mathrm{db})=\mathrm{n}-\mathrm{k}-1$.

c. Menentukan Kriteria pengujian $\mathrm{H}_{\mathrm{o}}$ ditolak apabila $\mathrm{F}$ hitung $>\mathrm{F}$ tabel, $\mathrm{H}_{\mathrm{a}}$ diterima apabila $\mathrm{F}$ dihitung $\leq \mathrm{F}$ tabel

d. Kesimpulan

$\mathrm{H}_{\mathrm{o}}$ ditolak artinya ada pengaruh kompetensi dan motivasi secara 
simultan terhadap kinerja karyawan PT. Bank BNI 46 (Persero) Tbk Unit Kartu Kredit Palembang.

$\mathrm{H}_{\mathrm{o}}$ diterima artinya tidak ada pengaruh kompetensi dan motivasi secara simultan terhadap kinerja karyawan PT. Bank BNI 46 (Persero) Tbk Unit Kartu Kredit Palembang.

\subsubsection{Uji t}

Pengujian hipotesis secara individual merupakan pengujian hipotesis koefisien regresi berganda dengan hanya satu $B\left(B_{1}\right.$ atau $\left.B_{2}\right)$ yang mempengaruhi $Y$. Langkah-langkah dalam uji hipotesis secara parsial atau individual yaitu:

a. Merumuskan Hipotesis

$\mathrm{H}_{\mathrm{o}}$ : Tidak ada pengaruh kompetensi dan motivasi secara individual terhadap kinerja karyawan PT. Bank BNI 46 (Persero) Tbk Unit Kartu Kredit Palembang.

$\mathrm{H}_{\mathrm{a}}$ : Kompetensi dan Motivasi berpengaruh terhadap kinerja karyawan PT. Bank BNI 46 (Persero)

Tbk Unit Kartu Kredit Palembang

b. Menentukan Taraf Nyata

Tingkat signifikan sebesar 5\%, Taraf nyata dari $t$ tabel ditentukan dari derajat bebas $(\mathrm{db})=\mathrm{n}-\mathrm{k}-1$, Taraf nyata (a) berarti nilai $t$ tabel, Taraf nyata dari $\mathrm{f}$ tabel ditentukan dengan derajat bebas $(\mathrm{db})=\mathrm{n}-\mathrm{k}-1$

c. Kriteria Pengujian

$\mathrm{H}_{\mathrm{o}}$ diterima dan $\mathrm{H}_{\mathrm{a}}$ ditolak apabila $\mathrm{t}$ hitung $\leq \mathrm{t}$ tabel

$\mathrm{H}_{\mathrm{o}}$ ditolak dan $\mathrm{H}_{\mathrm{a}}$ diterima apabila $\mathrm{t}$ hitung $>\mathrm{t}$ tabel

d. Kesimpulan

$\mathrm{H}_{\mathrm{o}}$ ditolak dan $\mathrm{H}_{\mathrm{a}}$ diterima, artinya ada pengaruh kompetensi dan motivasi terhadap kinerja karyawan PT. Bank BNI 46 (Persero) Tbk Unit Kartu Kredit Palembang.

$\mathrm{H}_{\mathrm{o}}$ diterima dan $\mathrm{H}_{\mathrm{a}}$ ditolak, artinya tidak ada pengaruh kompetensi dan motivasi terhadap kinerja karyawan PT. Bank BNI 46 (Persero) Tbk Unit Kartu Kredit Palembang.

\subsubsection{Analisis Koefisien Determinasi (R)}

Menurut Hasan, M. Iqbal (2012:236) apabila koefisien korelasi dikuadratkan, akan menjadi koefisien penentu (KP) atau koefisien determinasi, yang artinya penyebab perubahan pada variabel $\mathrm{Y}$ yang datang dari variabel, sebesar kuadrat koefisien korelasinya. Koefisien determinasi ini menjelaskan besarnya sumbangan nilai suatu variabel (variabel $\mathrm{X}$ ) terhadap naik/turunnya (variasi) nilai variabel lainnya (variabel Y).

Nilai (R) beriksar antara 0 sampai dengan 1. Semakin mendekati 1 maka variabel terikat atau merupakan indikator yang menunjukan semakin mempengaruhi kemampuan menjelaskan perubahan variabel bebas terhadap variabel terikat.

\section{HASIL PENELITIAN DAN PEMBAHASAN}

\subsection{Gambaran Umum Perusahaan}

Menurut sejarah di kota Palembang memiliki pasar terbesar yaitu 16 ilir. Pasar yang berdiri dari tahun 1821 atau pada zaman kesultanan Palembang Darusalam ini menjadi tempat wisata belanja bagi masyarakat Palembang.

Akses menuju pasar ini bisa melalui kendaraan darat maupun kendaraan air (Sungai Musi). Barang yang bisa ditemukan mulai dari kebutuhan rumah tangga, sayur mayur, buah-buahan, elektronik, perkakas mesin, gorden, segala jenis kain, aneka kuliner hingga pusat oleh-oleh dengan harga yang relative murah. Lokasi penelitian ini yaitu PT. Bank Negera Indonesia 46 unit kartu kredit Palembang, yaitu berada dipusat kota dengan tingkat keramaian yang sangat padat yaitu didaerah pasar 16 ilir. 


\subsection{Hasil Penelitian}

Peneliti mendapatkan data dengan membagikan kuesioner kepada karyawan. Kriteria penilaian pemilihan ini di ukur dengan skala Likert. Menurut Sugiono (2006:80) pemilihan skala Likert didasarkan pada pertimbangan bahwa penelitian ini digunakan untuk mengukur sikap, pendapat dan persepsi responden tentang fenomena sosial yang ada disekitarnya. Kuesioner yang dibagikan secara langsung oleh penulis kepada responden yang ditemui secara langsung.

Kuesioner yang akan digunakan dalam penelitian ini merupakan pernyataan mengenai pengaruh kompetensi dan motivasi terhadap kinerja karyawan PT. Bank Negera Indonesia 46 (persero) tbk unit kartu kredit Palembang.

\subsection{Pembahasan}

4.3.1 Validasi Data

\section{Variabel Kompetensi (X1)}

Hasil pengolahan data untuk mengetahui variabel yang diteliti valid atau tidak, Berikut pengujian validitas pada variabel Kompetensi (X1). Hasil selengkapnya dapat dilihat pada tabel dibawah ini:

Tabel 4.1

Hasil Uji Validitas Kompetensi

\begin{tabular}{|c|c|c|c|c|}
\hline No & Keterangan & $\begin{array}{c}\text { Corrected Item }- \text { Total } \\
\text { Correlatio }(\text { hitung })\end{array}$ & $\mathrm{r}_{\text {tabel }}(\mathrm{a}=5 \%)$ & Hasil Validitas \\
\hline 1 & $\mathrm{X}_{1 . \mathrm{P}_{1}}$ & 0,418 & 0.361 & Valid \\
\hline 2 & $\mathrm{X} 1 . \mathrm{P}_{2}$ & 0,646 & 0.361 & Valid \\
\hline 3 & $\mathrm{X} 1 . \mathrm{P}_{3}$ & 0,497 & 0.361 & Valid \\
\hline 4 & $\mathrm{X} 1 . \mathrm{P}_{4}$ & 0,466 & 0.361 & Valid \\
\hline 5 & $\mathrm{X}_{4} . \mathrm{P}_{5}$ & 0,522 & 0.361 & Valid \\
\hline 6 & $\mathrm{X} 1 . \mathrm{P}_{6}$ & 0,529 & 0.361 & Valid \\
\hline
\end{tabular}

Sumber: Pengolahan data SPSS Versi 22

Dari hasil analisis didapat nilai Corrected Item Total Correlatio ( $r$ hitung) antara skor item dengan skor total. Nilai ini kemudian dibandingkan dengan nilai $r_{\text {tabel }}$, $\mathrm{r}_{\text {tabel }}$ dicari pada signifikansi 0.05 dengan uji 2 sisi dan jumlah data $(n)=72$ maka didapat $\mathrm{r}_{\text {tabel }}$ sebesar 0361. Berdasarkan hasil analisis ini di dapat nilai Corrected Item Total Correlation $\left(\mathrm{r}_{\text {hitung }}\right.$ ) untuk semua item lebih besar dari 0.361 maka dapat disimpulkan bahwa item - item tersebut berkolerasi signifikan dengan skor total (dinyatakan valid) sehingga dapat disimpulkan bahwa semua butir instrument tersebut valid.

\section{Variabel Motivasi (X2)}

Hasil pengolahan data untuk mengetahui variabel yang diteliti valid atau tidak, Berikut pengujian validitas pada variabel Motivasi (X2). Hasil selengkapnya dapat dilihat pada tabel dibawah ini:

Tabel 4.2

Hasil Uji Validitas Motivasi

\begin{tabular}{|c|c|c|c|c|}
\hline No & Keterangan & $\begin{array}{c}\text { Corrected Item }- \\
\text { Total Correlation }\end{array}$ & $\mathrm{r}_{\text {tabel }}(\mathrm{a}=5 \%)$ & Hasil Validitas \\
\hline 1 & $\mathrm{X} 2 . \mathrm{P}_{1}$ & 0.706 & 0.361 & Valid \\
\hline 2 & $\mathrm{X} 2 . \mathrm{P}_{2}$ & 0.706 & 0.361 & Valid \\
\hline
\end{tabular}




\begin{tabular}{|c|c|c|c|c|}
\hline 3 & $\mathrm{X}^{2} . \mathrm{P}_{3}$ & 0.685 & 0.361 & Valid \\
\hline 4 & $\mathrm{X}_{2} . \mathrm{P}_{4}$ & 0.585 & 0.361 & Valid \\
\hline 5 & $\mathrm{X}_{2} . \mathrm{P}_{5}$ & 0.580 & 0.361 & Valid \\
\hline 6 & $\mathrm{X} 2 . \mathrm{P}_{6}$ & 0.572 & 0.361 & Valid \\
\hline
\end{tabular}

Sumber: Pengolahan data SPSS Versi 22

Dari hasil analisis di dapat nilai Corrected Item Total Correlation ( $\mathrm{r}_{\text {hitung }}$ ) antara skor item dengan skor total. Nilai ini kemudian dibandingkan dengan nilai $r_{\text {tabel }}$, dicari pada signifikan 0.05 dengan uji 2 sisi dan jumlah data $(N)=72$ maka didapat $r_{\text {tabel }}$ sebesar 0.361. Berdasarkan hasil analisis ini didapat nilai Corrected Item Total Correlation ( $\mathrm{r}_{\text {hitung }}$ ) untuk semua item lebih besar dari 0.361 maka dapat disimpulkan bahwa item - item tersebut berkolerasi signifikan dengan skor total (dinyatakan valid) sehingga dapat disimpulkan bahwa semua butir instrument tersebut valid.

\section{Variabel Kinerja (Y)}

Hasil pengolahan data untuk mengetahui variabel yang diteliti valid atau tidak, Berikut pengujian validitas pada variabel Kinerja (Y). Hasil selengkapnya dapat dilihat pada tabel dibawah ini:

Tabel 4.3

Hasil Uji Validitas Kinerja

\begin{tabular}{|c|c|c|c|c|}
\hline No & Keterangan & $\begin{array}{c}\text { Corrected Item }- \\
\text { Total Correlation }\end{array}$ & $\mathrm{r}_{\text {tabel }}(\mathrm{a}=5 \%)$ & $\begin{array}{c}\text { Hasil } \\
\text { Validitas }\end{array}$ \\
\hline 1 & $\mathrm{Y}_{1} \cdot \mathrm{P}_{1}$ & 0.630 & 0.361 & Valid \\
\hline 2 & $\mathrm{Y}_{1} \cdot \mathrm{P}_{2}$ & 0.630 & 0.361 & Valid \\
\hline 3 & $\mathrm{Y}_{1} \cdot \mathrm{P}_{3}$ & 0.616 & 0.361 & Valid \\
\hline 4 & $\mathrm{Y}_{1} \cdot \mathrm{P}_{4}$ & 0.398 & 0.361 & Valid \\
\hline 5 & $\mathrm{Y}_{1} \cdot \mathrm{P}_{5}$ & 0.480 & 0.361 & Valid \\
\hline 6 & $\mathrm{Y}_{1} \cdot \mathrm{P}_{6}$ & 0.555 & 0.361 & Valid \\
\hline
\end{tabular}

Sumber: Pengolahan data SPSS Versi 22

Dari hasil analisis didapat nilai Corrected Item Total Correlation ( $\mathrm{r}_{\text {hitung }}$ ) antara skor item dengan skor total. Nilai ini kemudian dibandingkan dengan nilai $r_{\text {tabel }}$, $r_{\text {tabel }}$ dicari pada signifikan 0.05 dengan uji 2 sisi dan jumlah data $(n)=72$ maka didapat $\mathrm{r}_{\text {tabel }}$ sebesar 0.361. Berdasarkan hasil analisis ini didapat nilai Corrected Item Total Correlation ( $\mathrm{r}_{\text {hitung }}$ ) untuk semua item lebih besar dari 0.361 maka dapat disimpulkan bahwa item - item tersebut berkorelasi signifikan dengan skor total (dinyatakan valid) sehingga dapat disimpulkan bahwa semua butir instrument tersebut valid.

\subsubsection{Uji Reabilitas}

Metode pengujian reliabilitas yang digunakan dalam penelitian ini adalah Alpha - Cronbach. Standar hitung yang digunakan dalam menentukan reliable atau tidaknya suatu instrumen penelitian adalah perbandingan antara nilai $r$ - hitung dengan $r$ - tabel pada taraf signifikan 5\%. Apabila dilakukan pengujian reliabilitas dengan metode Alpha - Cronbach. Kemudian untuk menentukan data relabel atau tidak yakni dengan menggunakan analisis SPSS Versi 22. Hasil pengolahan tersebut dapat dilihat pada tabel berikut: 
Tabel 4.4

Hasil Uji Reliabilitas

\begin{tabular}{|c|c|c|c|}
\hline Item & Cronbach's Alpha & Standar Reliabilitas & Hasil Reliabilitas \\
\hline $\mathrm{X} 1$ & 0.752 & 0,60 & Reliabel \\
\hline $\mathrm{X} 2$ & 0.835 & 0,60 & Reliabel \\
\hline $\mathrm{Y}$ & 0.774 & 0,60 & Reliabel \\
\hline
\end{tabular}

Sumber: Hasil Pengolahan data SPSS Versi 22

Berdasarkan tabel diatas bahwa

seluruh nilai Cronbach's Alpha reliabel. Karena nilai seluruh Cronbach's Alpha, berdasarkan pengolahan data melalui SPSS 22 dilihat tabel di atas diperoleh nilai dalam kategori reliabilitas tinggi.

\subsection{Teknik Analisis}

\subsubsection{Analisis Regresi Linier Berganda}

Analisis regresi linier berganda ini digunakan untuk mengetahui pengaruh antara variabel Kompetensi dan Motivasi terhadap Kinerja. Hasil analisis tersebut dapat dilihat pada tabel berikut ini:

Tabel 4.5

Analisis Regresi Linier Berganda

\begin{tabular}{|l|r|r|r|r|r|}
\hline \multicolumn{7}{|c|}{ Coefficients $^{\mathbf{a}}$} \\
\hline \multirow{2}{*}{ Model } & \multicolumn{2}{|c|}{$\begin{array}{c}\text { Unstandardized } \\
\text { Coefficients }\end{array}$} & $\begin{array}{c}\text { Standardized } \\
\text { Coefficients }\end{array}$ & \multirow{2}{*}{ Sig. } & \\
\cline { 2 - 4 } & \multicolumn{1}{|c|}{ B } & Std. Error & Beta & & \\
\hline (Constant) &, 8.576 & 2.484 & & 3,452 &, 001 \\
\hline Kompetensi &, 223 &, 109 &, 239 & 2053. &, 004 \\
\hline Motivasi &, 397 &, 115 &, 402 & 3.450 &, 001 \\
\hline
\end{tabular}

Sumber: Hasil pengolahan SPSS, 2021

Hasil perhitungan tabel 4.5 melalui program SPSS versi 25 , diperoleh persamaan regresi linier berganda sebagai berikut:

$$
Y=8,576+0,223 X_{1}+0,397 X_{2}
$$

Nilai koefisien kompetensi sebesar 0,223 (positif), menunjukkan kompetensi berpengaruh positif terhadap kinerja karyawan PT. Bank BNI Persero Tbk Unit Kartu Kredit Palembang. Artinya apabila terjadi peningkatan pada kompetensi maka kinerja karyawan akan meningkat, dan sebaliknya apabila kompetensi menurun maka kinerja karyawan akan menurun.

Nilai koefisien motivasi sebesar 0,397 (positif), menunjukkan motivasi berpengaruh positif terhadap kinerja karyawan PT. Bank BNI Persero Tbk Unit Kartu Kredit Palembang. Artinya apabila terjadi peningkatan pada motivasi maka kinerja karyawan akan meningkat, dan sebaliknya apabila motivasi menurun maka kinerja karyawan akan menurun.

\subsubsection{Uji Hipotesis}

\section{Uji F (Simultan)}

Uji F (simultan) bertujuan untuk mengetahui apakah variabel kompetensi dan motivasi (secara simultan) berpengaruh terhadap variabel kinerja. Hasil uji $\mathrm{F}$ dapat dilihat pada tabel 4.6 berikut ini: 
Tabel 4.6

Hasil Uji F (Simultan)

\begin{tabular}{|c|c|c|c|c|c|}
\hline \multicolumn{6}{|c|}{ ANOVA $^{a}$} \\
\hline Model & $\begin{array}{c}\text { Sum of } \\
\text { Squares }\end{array}$ & Df & $\begin{array}{l}\text { Mean } \\
\text { Square }\end{array}$ & $\mathrm{F}$ & Sig. \\
\hline 1 Regression & 268.341 & 2 & 134.170 & 16.140 & $.000^{b}$ \\
\hline Residual & 573.604 & 69 & 8.313 & & \\
\hline Total & 841.944 & 71 & & & \\
\hline \multicolumn{6}{|c|}{ a. Dependent Variable: Kinerja karyawan } \\
\hline \multicolumn{6}{|c|}{ b. Predictors: (Constant), Motivasi, Kompetensi } \\
\hline
\end{tabular}

Sumber: Hasil pengolahan SPSS, 2021

Berdasarkan Tabel Anova di atas, dapat dilihat bahwa nilai $F_{\text {hitung }}(16,140)>$ $F_{\text {tabel }}(3,13)$, dengan tingkat sig.F $0,000<$ 0,05 (signifikan), maka Ho ditolak dan Ha diterima, artinya ada pengaruh kompetensi dan motivasi terhadap kinerja karyawan PT. Bank BNI Persero Tbk Unit Kartu Kredit Palembang.

\section{Uji t (Parsial)}

Uji $t$ (parsial) bertujuan untuk mengetahui apakah variabel kompetensi dan motivasi secara parsial berpengaruh terhadap variabel kinerja. Hasil uji t dapat dilihat pada gambar 4.28 berikut ini.

Tabel 4.7

Hasil Uji t (Parsial)

\begin{tabular}{|c|c|c|c|c|c|c|}
\hline \multicolumn{7}{|c|}{ Coefficients $^{a}$} \\
\hline & \multirow{2}{*}{ Model } & \multicolumn{2}{|c|}{$\begin{array}{l}\text { Unstandardized } \\
\text { Coefficients }\end{array}$} & \multirow{2}{*}{$\begin{array}{c}\begin{array}{c}\text { Standardized } \\
\text { Coefficients }\end{array} \\
\text { Beta }\end{array}$} & \multirow{2}{*}{$\mathbf{T}$} & \multirow{2}{*}{ Sig. } \\
\hline & & B & Std. Error & & & \\
\hline \multirow{3}{*}{1} & (Constant) & 8.576 & 2.484 & & 3.452 & .001 \\
\hline & Kompetensi & .223 & .109 & .239 & 2.053 & .004 \\
\hline & Motivasi & .397 & .115 & .402 & 3.450 & .001 \\
\hline
\end{tabular}

Sumber: Hasil pengolahan SPSS, 2021

Berdasarkan tabel diatas nilai $t_{\text {hitung }}$ untuk kompetensi sebesar $(2,053)>t_{\text {tabel }}$ (1,994), dengan tingkat sig.t $0,004<0,05$ (signifikan), maka Ho ditolak dan $\mathrm{Ha}$ diterima, artinya ada pengaruh kompetensi terhadap kinerja karyawan PT. Bank BNI Persero Tbk Unit Kartu Kredit Palembang.

Berdasarkan tabel diatas nilai $t_{\text {hitung }}$ untuk motivasi sebesar $(3,450)>t_{\text {tabel }}$ (1,994), dengan tingkat sig.t $0,001<0,05$ (signifikan), maka Ho ditolak dan $\mathrm{Ha}$ diterima, artinya ada pengaruh Motivasi terhadap kinerja karyawan PT. Bank BNI Persero Tbk Unit Kartu Kredit Palembang.

\section{Uji Koefisien Determinasi (R)}

Hasil perhitungan koefisien determinasi digunakan untuk mengetahui seberapa besar sumbangan variabel kepemimpinan, motivasi dan disiplin kerja secara simultan terhadap variabel terikat yaitu Kinerja PT. Bank BNI Persero Tbk Unit Kartu Kredit Palembang sebagai berikut : 
Tabel 4.8

Hasil Koefisien Determinasi

\begin{tabular}{|l|r|r|r|r|}
\hline \multicolumn{5}{|c|}{ Model Summary } \\
\hline $\begin{array}{l}\text { Mod } \\
\text { el }\end{array}$ & $\mathrm{R}$ & R Square & $\begin{array}{c}\text { Adjusted R } \\
\text { Square }\end{array}$ & $\begin{array}{c}\text { Std. Error of the } \\
\text { Estimate }\end{array}$ \\
\hline 1 & $.565^{\mathrm{a}}$ & .319 & .299 & 2.88324 \\
\hline a. Predictors: (Constant), Motivasi, Kompetensi \\
\hline
\end{tabular}

Sumber: Hasil pengolahan SPSS, 2021

Berdasarkan hasil perhitungan tabel diatas dengan menggunakan program SPSS dapat diinterprestasikan sebagai berikut:

Angka R Square (nilai koefisien determinasi $\left(\mathrm{R}^{2}\right)$ sebesar 0,299 memberikan makna bahwa variabel kompetensi dan motivasi hanya mampu menjelaskan perubahan terhadap kinerja PT. Bank BNI Persero Tbk Unit Kartu Kredit Palembang. sebesar 29,9 \%, sedangkan sisanya 70,1\% dijelaskan oleh variabel lain yang tidak termasuk dalam penelitian ini.

\section{V . KESIMPULAN DAN SARAN}

\subsection{Kesimpulan}

Berdasarkan hasil penelitian dan pembahasan yang telah dijelaskan sebelumnya, beberapa hal yang dapat disimpulkan dari penelitian ini antara lain sebagai berikut.

1. Dengan tingkat keyakinan $95 \%$ ada pengaruh kompetensi dan motivasi terhadap kinerja karyawan PT. Bank BNI Persero Tbk Unit Kartu Kredit Palembang.

2. Dengan tingkat keyakinan $95 \%$ ada pengaruh kompetensi dan terhadap kinerja karyawan PT. Bank BNI Persero Tbk Unit Kartu Kredit Palembang.

3. Dengan tingkat keyakinan $95 \%$ ada pengaruh motivasi terhadap kinerja karyawan PT. Bank BNI Persero Tbk Unit Kartu Kredit Palembang.

\subsection{Saran}

Berdasarkan kesimpulan yang ada pada penelitian ini, terdapat beberapa saran antara lain.

1. Berdasarkan hasil penelitian ini bahwa kompetensi berpengaruh terhadap kinerja karyawan, maka dapat disarankan perusahaan perlu memberikan programprogram pendidikan dan training yang sesuai dengan kebutuhan perusahaan agar kemampuan mereka dalam bekerja jauh lebih baik lagi.

2. Selain itu, berdasarkan hasil penelitian menunjukan bahwa motivasi berpengaruh terhadap kinerja karyawan, maka dapat disarankan agar perusahaan tetap menjalankan program pemberian penghargaan bagi karyawan untuk lebih meningkatkan motivasi karyawan lagi perusahaan dapat mensosialisasikan program pemberian penghargaan bagi karyawan.

\section{DAFTAR PUSTAKA}

Ariep, Ishak dan Hendri Tanjung, 2003. Manajemen Motivasi. Jakarta: Grasindo

Arikunto, S. 2010. Prosedur Penelitian Suatu pendekatan praktik. Jakarta: PT.Rineka Cipta

Armstrong, Michael dan Angela Baron, 1998. Performance Management. London: Institute of Personnel and Development. 
Apri Biman Santoso (2019). Pengaruh Kompetensi dan Motivasi Kerja Terhadap Kinerja Karyawan pada PT sumber berkah indonesia (SBI) (prabumulih).

Bintoro dan Daryanto, 2017, Manajemen Penilaian Kinerja Karyawan, cetakan pertama, Penerbit : Gava Media, Yogyakarta

Busro, Muhammad. 2018. Teori-Teori Manajemen Sumber Daya Manusia. Jakarta: Prenadameidia Group.

Deswita Rahmayanti (2019). Pengaruh kompetensi dan motivasi terhadap kinerja karyawan. Pada badan keuangan daerah kabupaten musi rawas utara.

Erny Amriani Asmin, A Rachman Supu (2019). Pengaruh kompetensi dan motivasi terhadap kinerja pegawai. Pada balai besar industri hasil perkebunan makasar.

Hasan, M.Iqbal. 2012. Pokok-Pokok Materi Statistik I (Statistik Deskriptif). Jakarta: Bumi Aksara

Hasibuan, Malayu (2016) Manajemen Dasar.Jakarta.edisi revisi.cetakan kedua belas.penerbit.PT.Bumi Aksara.

Hasibuan, Melayu. 2016. Manajemen Sumber Daya Manusia. Jakarta. edisi revisi. cetakan kesembilan belas.PT.Bumi Aksara.

Irmawati, Bakri Hasanudin, Hamida Adda (2019). Pengaruh kompetensi dan motivasi terhadap kinerja. Pada pekerja lapangan keluarga berencana dalam mengelola program keluarga berencana di palu.

Kasmir. 2019. Manajemen Sumber Daya Manusia. Depok. edisi pertama .cetakan kelima .penerbit. PT. Rajagrafindo Persada.
Kasmir. 2016. Manajemen Sumber Daya Manusia (Teori dan Praktik). Cetakan Kesatu. Jakarta:Raja Grafindo Persada.

Keputusan Kepala Badan Kepegawaian Negara Nomor 46A Tahun 2003 Tanggal 21 Nopember 2003.

Kreitner, Robert dan Angelo Kinicki. 2010. Organizational Behavior. New York: McGraw-Hill

Prof.Dr.Wibowo,S.E.,M.Phil(2017) Manajemen Kinerja. Depok. edisi kelima. cetakan kedua belas. PT.Rajagrafindo Persada.

Rivai, Veithzal. 2011, Manajemen Sumber Daya Manusia untuk Perusahaan: dari Teori ke Praktik, Jakarta : RajaGrafindo Persada

Ron, Rozada. 2020. Pengaruh komptensi, motivasi kerja, dan disiplin kerja terhadap kinerja dosen.pada fakultas ekonomi dan bisnis di universitas muhammadiyah gresik.

Simanjuntak. Payaman J. 2005. Manajemen dan Evaluasi Kinerja. Jakarta : FE UI.

Siregar, Sofyan. 2010. Statistika Deskriptif Untuk Penelitian. Jakarta: Pt Rajagrafindo Persada.

Sugiyono. 2017. Metode Penelitian Kuantitatif, Kualitatif, dan $R \& D$. Bandung : Alfabeta, CV.

Sugiyono. 2015. Metode Penelitian Kombinasi (Mix Methods). Bandung: Alfabeta

Sugiyono, 2013. Metode Penelitian Bisnis. (Cetakan ke-17) Bandung: Alfabeta.

Undang-Undang No. 13/2003 tentang Ketenagakerjaan: pasal 1 (10).

Zwell, Michael. 2000. Creating a Culture of Competence. New York: John Wiley \& Sons, Inc. 